\title{
Compositions of the essential oils of Ballota nigra subsp. uncinata and subsp. anatolica from Turkey
}

\author{
Ayla Kaya $^{1^{*}}$, Mine Kürkçüoğlu², Muhittin Dinç ${ }^{3}$, Süleyman Doğu ${ }^{3}$ \\ ${ }^{1}$ Department of Pharmaceutical Botany, Faculty of Pharmacy, Anadolu University, 26470 Eskisehir, TURKEY \\ ${ }^{2}$ Department of Pharmacognosy, Faculty of Pharmacy, Anadolu University, 26470 Eskisehir, TURKEY \\ ${ }^{3}$ Department of Biology, Ahmet Keleşoğlu Faculty of Education, Necmettin Erbakan University, 42090 Konya, TURKEY
}

\begin{abstract}
Background: Ballota nigra L. is a member of Lamiaceae family and is represented in the Flora of Turkey by five subspecies. Subsp. uncinata is a mediterranean element while subsp. anatolica is a Irano-Turanian phytogeographic region. Material and Methods: The essential oils from aerial parts of subsp. uncinata and subsp. anatolica were isolated by hydrodistillation. The analysis was performed by using a gas chromatography (GC) and gas chromatography-mass spectrometry (GC-MS) systems, simultaneously. Results: Twenty-two compounds were identified from the oil of subsp. uncinata representing $96.9 \%$ of the total oil and fourteen compounds were identified from the oil of subsp. anatolica representing $88 \%$ of the total oil. The major components were characterized as caryophyllene oxide (21.2\%), hexadecanoic acid (19.9\%), $\beta$-caryophyllene $(18.9 \%)$ for subsp. uncinata and hexadecanoic acid (40.9\%) and $\beta$-bisabolene (13.4\%) for subsp. anatolica, respectively.
\end{abstract}

Keywords: Ballota nigra, Essential oil, subsp. uncinata, subsp. anatolica, Turkey.

\section{INTRODUCTION}

The genus Ballota L. is a member of Lamiaceae family and comprised of about 90 species and widespread over the World. ${ }^{1}$ In Turkey, the genus Ballota is represented by 12 species and 8 subspecies. ${ }^{2-3}$ B. nigra is a perennial herb and bearing simple hairs. It is represented by five subspecies in Flora of Turkey. B. nigra is commonly distributed in Western Europe. ${ }^{4}$ B. nigra is known as "yalanc1 1sirgan" in Turkey and aerial parts of some subspecies of B. nigra are used to treat inflammation, as an antiseptic for wounds, and against gastrointestinal disorders. ${ }^{3,5}$ B. nigra subsp. anatolica is known as "gripotu" and has been used in folk medicine as an antiseptic, anti-inflammatory, anti-rheumatic, antioxidant, and antimicrobial agent, and also for nausea, vomiting, and nervous dyspepsia., ${ }^{1,6}$ The essential oil compositions of the B. nigra have been well documented in the literature and they mainly consist of sesquiterpenes and oxygenated sesquiterpenes. ${ }^{7-10}$ According to our literature survey, the volatile constituents of B. nigra subsp. anatolica have been previously investigated from Iran. ${ }^{1}$ However, no studies regarding $B$. nigra subsp. uncinata are reported in the literature. Mostprobably, this could be the first report on the essential oil chemical compositions of B. nigra subsp. anatolica and B. nigra subsp. uncinata from Turkey.

\section{Experimental \\ Plant material}

Plants were collected during the flowering period from Muğla (subsp. uncinata) and Konya (subsp. anatolica) province of Turkey. Voucher specimens are deposited in NEÜ Herbarium.

\section{Isolation of the Essential Oils}

The essential oils from air-dried plant materrials were isolated by hydrodistillation for $3 \mathrm{~h}$, using a Clevenger-type appa-
DOI: 10.5530ijper.51.3s.9 Correspondence:

Ayla Kaya,

Department of Pharmaceutical Botany, Faculty of Pharmacy,

Anadolu University, 26470

Eskisehir, TURKEY

Contact: +905326873635

E-mail: aykaya@anadolu.

edu.tr 
ratus. The obtained oils were dried over anhydrous sodium sulphate and stored at $+4^{\circ} \mathrm{C}$ in the dark until analysed and tested.

\section{GC-MS analysis}

The GC-MS analysis was carried out with an Agilent 5975 GC-MSD system. Innowax FSC column $(60 \mathrm{~m} \times$ $0.25 \mathrm{~mm}, 0.25 \mu \mathrm{m}$ film thickness) was used with helium as carrier gas $(0.8 \mathrm{~mL} / \mathrm{min}$.). GC oven temperature was kept at $60^{\circ} \mathrm{C}$ for $10 \mathrm{~min}$ and programmed to $220^{\circ} \mathrm{C}$ at a rate of $4^{\circ} \mathrm{C} / \mathrm{min}$, and kept constant at $220^{\circ} \mathrm{C}$ for $10 \mathrm{~min}$ and then programmed to $240^{\circ} \mathrm{C}$ at a rate of $1{ }^{\circ} \mathrm{C} / \mathrm{min}$. Set for Split less injection. The injector temperature was at $250^{\circ} \mathrm{C}$. MS were taken at $70 \mathrm{eV}$. Mass range was from $\mathrm{m} / \mathrm{z} 35$ to 450 .

\section{GC analysis}

The GC analysis was carried out using an Agilent $6890 \mathrm{~N}$ GC system. In order to obtain the same elution order with GC/MS, simultaneous injection was done by using the same column and appropriate operational conditions. FID temperature was $300^{\circ} \mathrm{C}$. Relative percentages of the separated compounds were calculated from integration of the peak areas in the GC-FID chromatograms.

\section{Identification of Compounds}

The components of essential oils were identified by comparison of their mass spectra with those in the Baser Library of Essential Oil Constituents, Adams Library, ${ }^{11}$ Mass Finder Library, ${ }^{12}$ Wiley GC/MS Library ${ }^{13}$ and confirmed by comparison of their retention indices. These identifications were accomplished by comparison of retention times with authentic samples or by comparison of their relative retention index (RRI) to a series of n-alkanes.

\section{RESULTS AND DISCUSSION}

The water-distilled essential oils from aerial parts of B. nigra subsp. uncinata and B. nigra subsp. anatolica were characterized by GC-FID and GC-MS in this study. The compounds identified from the essential oils along with their relative percentages are listed in Table $1 \mathrm{~A}$ total of 22 and 14 compounds were identified from the essential oils of subsp. uncinata and subsp. anatolica respectively, which represented 96.9 and $88 \%$ of the oils. Components of the oils can be grouped into three and five main chemical classes in subsp. uncinata and subsp. anatolica, respectively. The oil isolated from subsp. uncinata was dominated by sesquiterpene hydrocarbones (34.4\%), oxygenated sesquiterpenes $(32.6 \%)$ and other contents $(29.9 \%)$ and caryophyllene oxide $(21.2 \%)$, hexadecanoic acid $(19.9 \%)$ and $\beta$-caryophyllene (18.9\%) being the main compounds. However, the oil of subsp. anatolica was characterized by a high content of others $(59.3 \%)$, sesquiterpene hydrocarbones $(18.9 \%$ ) and a low percentage of oxygenated sesquiterpenes $(5.4 \%)$, diterpene $(2.7 \%)$, oxygenated monoterpenes $(1.7 \%)$ and hexadecanoic acid $(40.9 \%)$ and $\beta$-bisabolene $(13.4 \%)$ being the main compounds.

The essential oil of several Ballota nigra has been previously studied. In 2003, Bader et al. ${ }^{7}$ reported $\beta$-caryophyllene $(25.1 \%)$ and germacrene $\mathrm{D}(24.2 \%)$ as the main compounds of B. nigra subsp. foetida from Jordan. Monoterpenes were little represented, while sesquiterpenes were present in large amounts in their study. In a study of Semnani et al. ${ }^{8}, 42$ components were identified in Iranian B. nigra oil, which presented about $95.4 \%$ of the total composition of the oil. Caryophyllene oxide $(7.9 \%)$, epi- $\alpha$-muurolol $(6.6 \%), \delta$-cadinene $(6.5 \%)$, and $\alpha$-cadinol $(6.3 \%)$ were found to be the main constituents. A literature survey has shown that there is one report on the volatile constituents of $B$. nigra subsp. anatolica growing in Iran. ${ }^{1}$ Twelve compounds were identified, representing $91.8 \%$ of the total oil and germacrene D $(18.1 \%)$, nerolidol epoxyacetate $(15.4 \%)$, sclareol oxide $(12.1 \%)$, linalyl acetate $(11.5 \%)$, and $\beta$-caryophyllene $(10.5 \%)$ were found to be the main constituents. This oil consisted of oxygenated monoterpenes $(18.1 \%)$, sesquiterpene hydrocarbons $(32.5 \%)$, and oxygenated sesquiterpenes (41.2\%). Oil composition of our B. nigra subsp. anatolica was found to be quite different from those already reported. According to Vukovic et al. ${ }^{9}$ B. nigra produces two types of essential oils: the first was associated with the stem and leaf and the second was typical of the root. The first type of the oil should be considered a sesquiterpene hydrocarbon-rich oil, dominated by $\beta$-caryophyllene and germacrene D. In contrast to the stem and leaf oils, the root produced an oxygenated monoterpene-rich oil in which the 17 monoterpenes accounted for more than $43 \%$ of the oil. In 2014, Fraternale and Ricci ${ }^{10}$ reported $\beta$-caryophyllene $(22.6 \%$ and $21.8 \%)$, caryophyllene oxide $(18.0 \%$ and $20.5 \%)$ and germacrene-D (16.5 and $13.1 \%$ ) as major compounds of B. nigra subsp. foetida.

$\beta$-caryophyllene and caryophyllene oxide, main compounds for our subsp. uncinata, similar to main compounds of subsp. foetida ${ }^{7,10}$ B. nigra ${ }^{8-9}$ and B. nigra subsp. anatolica. ${ }^{1}$ However, hexadeconoic acid and $\beta$-bisabolene are main compounds in oil of our subsp. anatolica and these main compounds were not seen other B. nigra. The difference in the oil composition of the present study and previous research may be due to the collection time, chemotypes, drying conditions, mode of distillation, and geographic and climatic factors. ${ }^{8}$ 
Table 1: The composition of the essential oil of subspecies of Ballota nigra

\begin{tabular}{|c|c|c|c|c|}
\hline RRI & Compounds & $\begin{array}{c}\underset{\%}{\text { subsp. uncinata }} \\
\%\end{array}$ & $\begin{array}{c}\text { subsp. anatolica } \\
\%\end{array}$ & ID \\
\hline 1306 & Geijerene & 0.3 & - & $\mathrm{ms}$ \\
\hline 1353 & Tridecene & 0.8 & - & $\mathrm{ms}$ \\
\hline 1495 & Bicycloelemene & 1.8 & - & $\mathrm{ms}$ \\
\hline 1497 & a-Copaene & 0.8 & - & $\mathrm{ms}$ \\
\hline 1553 & Linalool & - & 1.7 & $t_{R}, m s$ \\
\hline 1612 & $\beta$-Caryophyllene & 18.9 & 2.7 & $\mathrm{t}_{\mathrm{R}}, \mathrm{ms}$ \\
\hline 1687 & a-Humulene & 1.3 & - & $t_{R}, m s$ \\
\hline 1726 & Germacrene D & 4.6 & - & $\mathrm{ms}$ \\
\hline 1737 & $\beta$-Bisabolene & - & 13.4 & $t_{R}, m s$ \\
\hline 1740 & a-Muurolene & 0.8 & - & $\mathrm{ms}$ \\
\hline 1742 & $\beta$-Selinene & 1.3 & - & $\mathrm{ms}$ \\
\hline 1746 & Selina- 4(15), 7(11)-diene & - & 0.9 & $\mathrm{~ms}$ \\
\hline 1755 & Bicyclogermacrene & 3.7 & - & $\mathrm{ms}$ \\
\hline 1773 & ס-Cadinene & 1.2 & 0.7 & $t_{R}, m s$ \\
\hline 1783 & $\beta$-Sesquiphellandrene & - & 1.2 & $\mathrm{~ms}$ \\
\hline 1868 & $(E)$-Geranyl acetone & - & 1.1 & $t_{\mathrm{R}}, \mathrm{ms}$ \\
\hline 1882 & 1-Isobutyl 4-isopropyl-2,2-dimethyl succinate & - & 6.6 & $\mathrm{~ms}$ \\
\hline 2008 & Caryophyllene oxide & 21.2 & - & $\mathrm{t}_{\mathrm{R}}, \mathrm{ms}$ \\
\hline 2131 & Hexahydrofarnesyl acetone & 4.4 & 7.9 & $t_{R}, m s$ \\
\hline 2144 & Spathulenol & 4.2 & - & $t_{R}, m s$ \\
\hline 2192 & Copaborneol & - & 1.9 & $\mathrm{~ms}$ \\
\hline 2257 & $\beta$-Eudesmol* & 1.9 & 3.5 & $\mathrm{~ms}$ \\
\hline 2324 & Caryophylladienol II & 0.7 & - & $\mathrm{ms}$ \\
\hline 2353 & Caryophyllenol I & 0.8 & - & $\mathrm{ms}$ \\
\hline 2392 & Caryophyllenol II & 3.8 & - & $\mathrm{ms}$ \\
\hline 2503 & Dodecanoic acid & 0.7 & - & $\mathrm{t}_{\mathrm{R}}, \mathrm{ms}$ \\
\hline 2622 & Phytol & - & 2.7 & $\mathrm{~ms}$ \\
\hline 2696 & Tetradecanoic acid & 1.4 & 2.8 & $\mathrm{t}_{\mathrm{R}}, \mathrm{ms}$ \\
\hline 2700 & Heptacosane & 2.4 & - & $\mathrm{ms}$ \\
\hline \multirow[t]{7}{*}{2931} & Hexadecanoic acid & 19.9 & 40.9 & $\mathrm{~ms}$ \\
\hline & Oxygenated Monoterpenes & - & 1.7 & \\
\hline & Sesquiterpene Hydrocarbones & 34.4 & 18.9 & \\
\hline & Oxygenated Sesquiterpenes & 32.6 & 5.4 & \\
\hline & Diterpenes & - & 2.7 & \\
\hline & Others & 29.9 & 59.3 & \\
\hline & TOTAL \% & 96.9 & 88 & \\
\hline
\end{tabular}

RRI; Relative retention indices calculated against $n$-alkanes C8-C30. \%; calculated from the FID chromatograms tr; Trace (<0.1 \%); *impure; ID; identification method $t_{\mathrm{p} /}$ identification based on the retention times (tR) of genuine compounds on the HP Innowax column; ms, identified on the basis of computer matching of the mass spectra with those of the Wiley and MassFinder libraries and comparison with literature data.

\section{CONCLUSION}

The major components were characterized as caryophyllene oxide $(21.2 \%)$, hexadecanoic acid (19.9\%), $\beta$-caryophyllene $(18.9 \%)$ for subsp. uncinata and hexadecanoic acid $(40.9 \%)$ and $\beta$-bisabolene $(13.4 \%)$ for subsp. anatolica, respectively.

\section{ACKNOWLEDGEMENT}

The authors are thankful for the technical helping to the University of Anadolu.

\section{CONFLICT OF INTEREST}


None

\section{ABBREVIATIONS USED}

GC: Gas chromatography; GC-MS: Gas chromatography-mass spectrometry; FID: Flame Ionization Detector; GC-FID: Gas chromatography with Flame Ionization Detector; ID: Identification method RRI: Relative retention indices; TR: Trace; $\mathrm{tR}$, identification based on the retention times; tR: of genuine compounds on the HP Innowax column; ms: identified on the basis of computer matching of the mass spectra with those of the Wiley and MassFinder libraries and comparison with literature data.

\section{REFERENCES}

1. Kazemizadeh Z, Amini T, Nazari F, Habibi Z. Volatile constituents of Ballota nigra subsp. anatolica from Iran. Chemistry of natural compounds. 2009;45(5):737-8.

2. Davis PH, Doroszenko A. Ballota. In: Davis, P H. et al. (eds.), Flora of Turkey and the East Aegean Islands, Edinburgh: University Press, Edinburgh 1982.

3. Güner A, Aslan S, Ekim T, Vural M, Babaç MT. Türkiye Bitkileri Listesi (Damarlı Bitkiler). İstanbul: Nezahat Gökyiğit Botanik Bahçesi ve Flora Araştırmaları Derneği Yayını, 2012.

\section{PICTORIAL ABSTRACT}

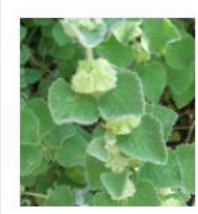

Ballota nigra
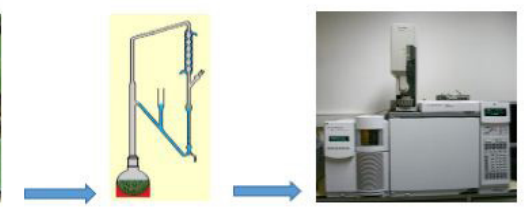

GC-MS

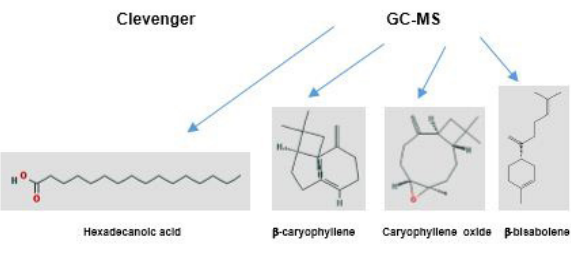

\section{About Authors}

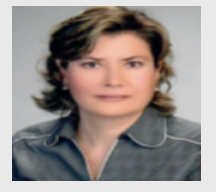

Prof. Dr. Ayla KAYA: She has completed her Ph. D. from Dept. of Pharmacognosy, Anadolu University. Her area of research interest is plant taxonomy, plant morphology, plant anatomy, palinology, ethnobotany, phytochemistry, essential oils. She has published more than 50 research papers in international journals. Currently she is a Professor of Pharmaceutical Botany at Anadolu University.

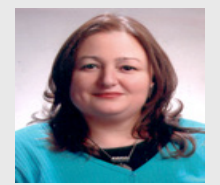

Prof. Dr. Mine Kürkçüoğlu: She is a researcher with 30 years experience working with medicinal and aromatic plants. She worked at the Medicinal and Aromatic Plant and Drug Research Centre from 1985-2002, and currently a Professor of Pharmacognosy at Anadolu University.

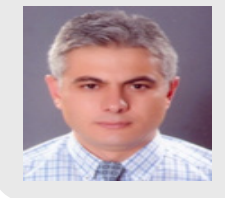

Prof Dr. Muhittin Dinç: He is presently working as Professor, Department of Biology, Necmettin Erbakan University Konya, Turkey. His major research area and publications are Plant taxanomy, plant morphology, plant anatomy, palinology, ethnobotany, phytochemistry. He has published more than 60 research papers in international journals. 
Ass. Prof. Dr. Süleyman Doğu: He is presently working as Assistant Professor, Department of Biology, Necmettin Erbakan University Konya, Turkey. His major research area and publications are Plant taxanomy, plant morphology, plant anatomy, palinology, ethnobotany, phytochemistry. He has published more than 40 research papers in international journals.

Cite this article: Kaya A, Kürkçüoglu M, Dinç M, Dogu S. Compositions of the essential oils of Ballota nigra subsp. uncinata and subsp. anatolica from Turkey. Indian J of Pharmaceutical Education and Research. 2017;51(3) Suppl:S185-89. 